\title{
鹿児島発 焼酎学講座
}

\section{鮫島吉廣}

鹿児島大学農学部

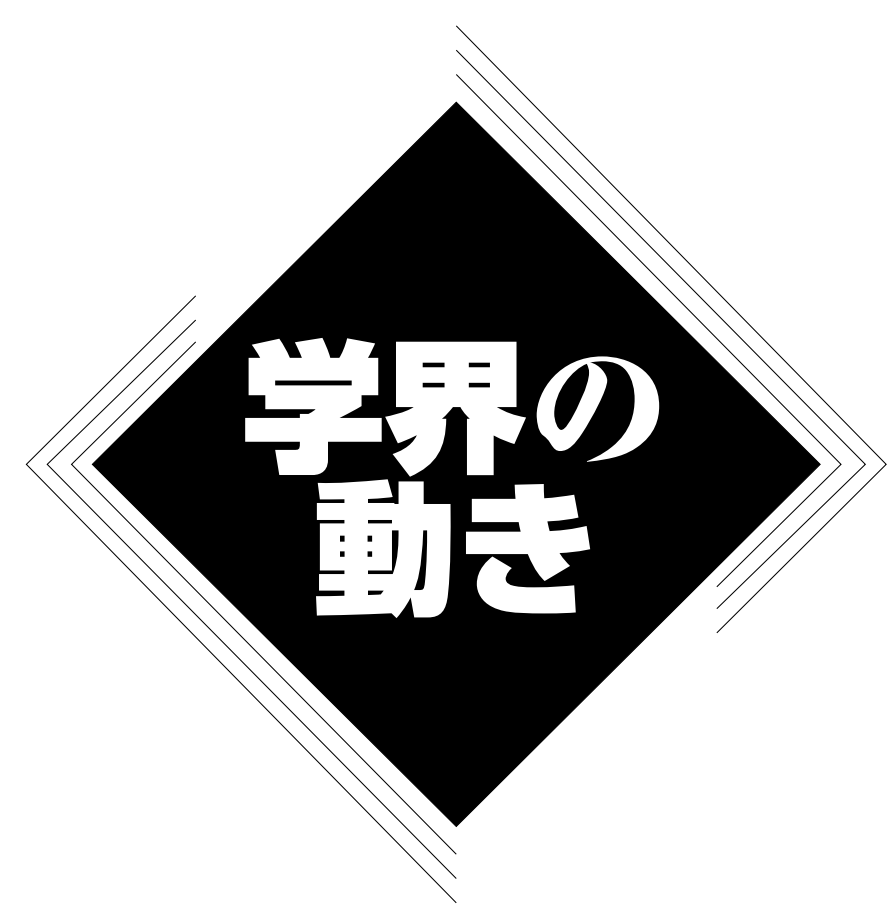

なぜ焼酎学講座か

酒は担税物資之嗜好飲料の二面性をもっている．明治 政府は近代国家建設のために地租と酒税を 2 大財源之 し, 酒税は国家財源の大きな一翼を担ってきた. 今では, 酒税の国家財源に占める地位は大きく低下したものの, 担税物資としての酒と民族の文化的産物としての酒のせ めぎあいは続き，酒税法の改定に業界が一喜一憂する体 制は変わることなく続いている.

また国際化の進展の中で, 酒税が国際紛争の火種に なったことも近年の特筆すべき点である.1987 年の GATT（関税之貿易に関する一般協定）勧告は焼酎や二 級ウイスキーなど大衆の酒の大幅増税を招き, 日本の酒 文化ともいえる清酒やウイスキーの級別廃止をもたらし た，さらには，WTO (世界貿易機関) の第 1 号の国際紛 争にウイスキーやブランデーと焼酎の酒税格差が取り上 げられ，1996 年日本は敗北し，焼酎の大幅増税を余儀な くされた。スコッチウイスキーと芋焼酎は「直接競合ま たは代替商品であり」，同じ酒税を課すべきという論理 がグローバルスタンダードになってしまったのである.

地球の裏側で, 知らない間に国際紛争に巻き込まれ敗北 に至ったことは，地域の零細な業界といえども国際的動 きを常に視野に入れ，そして西洋の蒸留酒とは異なる特 性をもつ日本の焼酎の独自性を，地域が自らアピールす る必要のあることを痛切に教える結果となった。

このような状況を受けて, 酒の世界は大きく様変わり した。 とりわけ，相次ぐ増税で壊滅的影響を受けると思 われた焼酎の，ここ 30 年来の伸びは目を見張るものが ある. 今や，本格焼酎の酒税は 2005 年度で 1,273 億円に 達し, 清酒の 917 億円を大きく上回るまでになった。こ 
のうち鹿児島県の酒税額は 384 億円であり, 実に清酒全 体の 4 割相当に匹敵する額を鹿児島県の焼酎メーカーが 納税しているのである。鹿児島県産焼酎の伸びは著しい ものがあり，鹿児島県経済の牽引役を担うまでになり， 焼酎クラスターとも呼ぶべき広がりをつくり出し, 焼酎 業界の動向は農業をはじめとする産業界全体に大きな影 響を及ぼすまでになった。

ただ，ここにきて，好調な市場の裏で，その将来が懸 念される事態も散見されるようになった．国内大手酒類 資本や海外産焼酎, そして甲乙混和焼酎の参入が相次 ぎ，焼酎が全国版になりつつある中で競争が激化し，焼 酎の特色である地域の個性や風土性が埋没しかねない状 況が生まれつつある。その対応のため, 鹿児島県酒造業 界は,「琉球」泡盛,「壱岐」焼酎,「球磨」焼酎に続き, 「薩摩」焼酎の, WTO の知的所有権の貿易関連の側面に 関する協定である TRIPS 協定の国際認証を取得した.

これにより，鹿児島産のサツマイモを原料にして，鹿児 島で造られたものだけが「薩摩」焼酎を名乗れることに なった，芋焼酎が国籍不明にならないよう，また薩摩芋 焼酎のブランド化を図るために投じた一石である。 そし て, 原料や燃料価格の高騰, 焼酎粕処理などによるコス トアップ要因が経営を圧迫しつつあり，また長年，焼酎 製造技術の担い手であり，焼酎文化そのものでもあった 焼酎杜氏が高齢化し，技術や文化の担い手の育成が急務 となってきた。

このように, 技術の伝承, 地域ブランドの確立, 競争 力の強化, 国際化への対応が求められる状況の中で, 焼 酎学講座設立の動きが始まった。

\section{地域をあげての支援体制}

焼酎学講座設立構想は, 教育・研究に加えて社会貢献 を大きな柱に掲げる鹿児島大学が, 研究・社会連携担当 の竹田靖史理事を中心として, 南九州を中心とする地域 産業の振興につながり，ものつくりを通じ地域産業・伝 統文化に興味をもつ人材を育成し, 地域社会の発展と活 性化に寄与する方策を県内外の関係者と協議する中で, 浮かび上がってきたものである. 2005 年の夏, 学内調整 を進めるうちに強力な助っ人が現われた. 九州大学産学 官連携広域コーディネータの砂田向壱客員教授, 日本政 策投資銀行南九州支店, 電通九州鹿児島支社などであ る. 直ちに大手焼酎会社 10 社, 酒造組合, 大学, 県を含 めたワーキンググループを結成し, 設立準備委員会を立 ち上げ，2006 年 2 月には伊藤祐一郎鹿児島県知事が 5,000 万円の寄附をする旨の新聞発表を行ない, 3 月には

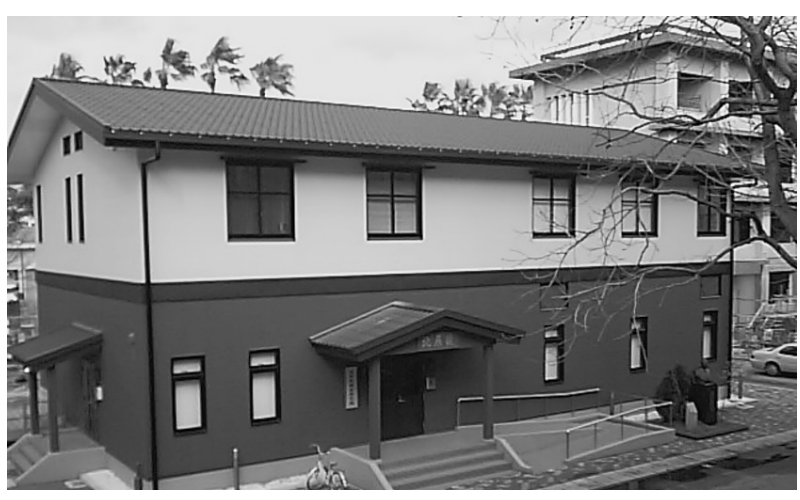

図 1 - 焼酎学講座研究棟「北辰蔵」

鹿児島県酒造組合が 5,000 万円，鹿児島県の焼酎会社全 社で 4 億円の寄附を行なう包括連携協定書を鹿児島県酒 造組合と結んだ. 5 年間で総額 5 億円の寄附講座である. 協定書における設立目的には「鹿児島の誇る焼酎文化を 継承発展させ，世界ブランドとしての地位を確固たるむ のにするとともに焼酎文化の継承者を育成し，むって地 域社会の発展に寄与することを目的とする」とあり，そ のために「農学部内に全学共通の焼酎学講座を設置し, 全学的な支援体制を構築する」となっている.

これを受けて 2006 年 4 月, 焼酎学講座は, 後述の故蟹 江松雄先生の出身母体で，焼酎と深いかかわりをむって きた農学部の生物資源化学科内に設置された。構想から 1 年後のことである。 2007 年 7 月には焼酎学講座研究棟 が完成し, 酒蔵を思わせる和風の研究棟は鹿児島大学の 歌として知られる「北辰斜に（ほくしんななめに）」にち なみ，また焼酎研究の拠点となることを願って「北辰蔵」 （北辰は北極星の意）と名づけられた（図 1).12月には 北辰蔵の前に蟹江松雄先生の胸像が関係者の篤志により 建立された，鹿児島大学では，農学部でサツマイモや焼 酎品質の研究を, 工学部で蒸留の研究など半世紀を超え る焼酎研究の歴史があるが，その先駆けとして精力的に 研究に取り組まれ，また焼酎をはじめとする地域産業の 振興に尽力されたのが, 昭和 21 年に赴任され, 後に学長 を務められた蟹江松雄先生である，焼酎学講座はこの長 年にわたる大学と地域産業界との交流の上に実現したも のでもあることから, 胸像は産学連携のシンボルとして の意味をもつものである.

\section{何を学び，研究し，発信するか}

焼酎学講座は, 焼酎製造学研究室と醸造微生物学研究 室の 2 つの研究室からなる。 まず東京農業大学の小泉武 夫教授が客員教授として招聘され，ついで 2006 年 4 月 


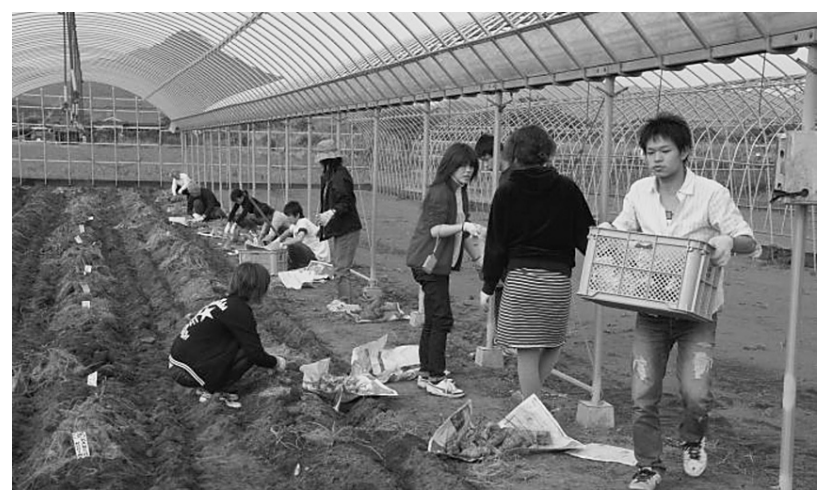

図 2・サツマイモ掘り取り

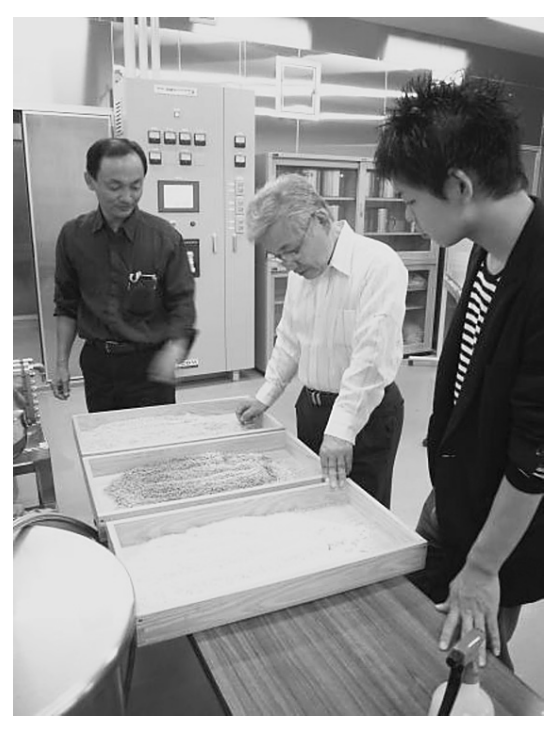

図 3 ロこうじ造り

に鹿児島県工業技術センターから高峯和則氏が焼酎製造 学准教授として赴任し, 開講の準備に当たった. 10 月に は焼酎メーカーから筆者が焼酎製造学教授に, 11 月に元 (独) 酒類総合研究所の伊藤清氏が醸造微生物学研究室教 授, 2007 年 3 月に京都大学から玉置尚徳氏が醸造微生物 学研究室准教授，4月に尾花由美子氏が焼酎製造学研究 室助教と 5 人の体制が整い, 2007 年 4 月に開講の運びと なった. 地域色の高い, 日本で初めての講座とあって地 域の関心が高く, 最初の授業風景は地元紙の一面を飾 り, 地元テレビ局は 2 週続けてゴールデンタイムに特集 を組んだほどである。

現在 3 年生が 10 名 (うち女性 4 名),「再チャレンジ支 援プログラム」社会人特別選抜の大学院生 4 名が学んで いる。焼酎学講座は焼酎製造技術を柱に, その背景と なった文化, 歴史, 風土を学び,「ものつくり」教育を通 じて, 焼酎文化と技術を継承し， かつ新技術開発のリー ダーとなる人材を期待されていることから, 企業現場で

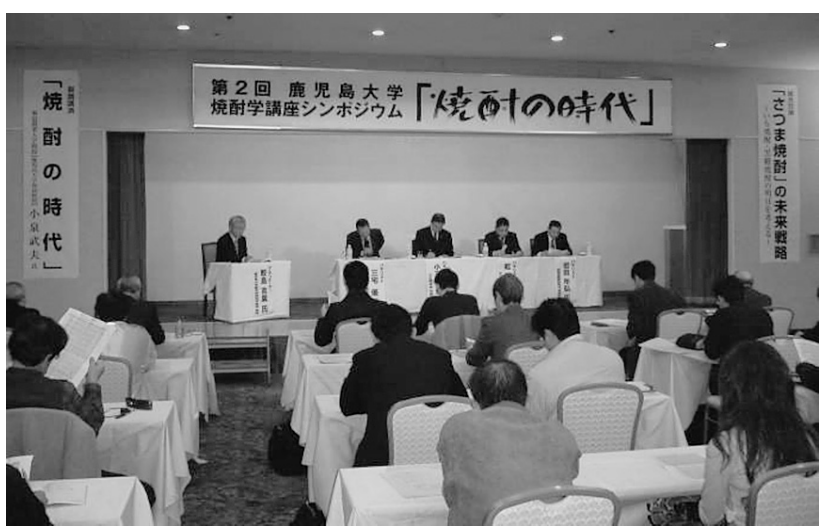

図 4 - 焼酎学講座シンポジウム

の製造実習を取り入れ（図 2)，講義では焼酎を体系的に 学ぶとともに（図 3), 全学的支援を得て, 焼酎文化論, バイオマス資源学, 感性心理学, 経営実学, 薩摩の歴史 と焼酎など，多彩な内容が盛り込まれている。

焼酎製造学研究室では，焼酎製造技術の習得や世界の 酒との比較を通じて焼酎の独自性を学ぶとともに，これ からの発展に向けた焼酎製造技術の開発を行なう。醸造 微生物学研究室は, 趜や酵母の研究を主体に, 有用微生 物の育種や収集を行ない，その特性解明を通じて新たな 酒質の創造を図るとともに，醸造微生物の新たな可能性 を探る。

対外的には焼酎学講座シンポジウムを開催し（図 4), 広く一般の人たちへの啓蒙活動を行なっている。これま で「再生する焼酎粕」,「焼酎の時代」,「奄美の食之黒糖 焼酎」,「夢あるアジアの発醳の世界」のテーマで 4 回開 催された。

焼酎学講座が関与する社会人教育の場としては，かご しまルネッサンスアカデミーがある。これは文部科学省 からの科学技術振興調整費により平成 18 年度から 22 年 度までの 5 年間行なわれるもので, 学内, 学外から多彩 な講師陣を招き，土日を中心に講義や実習が行なわれて いる．内容は，焼酎を中心とする鹿児島県の食文化の創 造之, 食産業の発展に寄与し地域の再生に資する人材の 育成を目的に, 醸造・発酵関連の食品産業に扔ける安全 と品質管理などの高度技術を教える「食の安全管理コー ス」, 急速な技術革新や市場二ーズの変化に戦略的に対 応できる技術マネジメント力を伸ばす「経営管理コー ス」, 歴史・文化・環境をはじめ, 健康・長寿など, 鹿児 島の食の魅力を発信し, 地域再生に取り組む人材を養成 する「健康・環境・文化コース」の 3 つのコースがあり， 毎年 50 名程度が学んでいる。 


\section{目指すもの}

酒は本来，地域の原料を使って地域で生産し，地域で 消費されてきたものである. 製造技術も地域の原料と気 候風土に即応した形で改良発展してきた. 20 世紀の技術 は良いものを大量に，そして安価に造ることに大きく貢 献した，だが，その一方で, 酒質は画一化し, 多彩な酒 文化の世界が失われ，風土性の歪失を招いた感がある。 そして今，技術の功罪が問われている，一方，いつでも どこでも誰でも飲める時代になって，酒の社会性が問わ れるようになった。これらの答えは原点回帰の中に求め るべきと考えている.

焼酎はきわめて地域性の高い酒である。鹿児島にあっ ては焼酎独自のクエン酸をつくり出す錮菌, クエン酸耐 性や耐熱性をもつ酵母など南国特有の微生物を使い, サ ツマイモの原料特性と温暖な気候を逆手にとって, 独自 の製法を編み出した，独特の酒質とお湯割りの飲み方は 醸造酒のように飲める蒸留酒という世界的にも稀な健康 的な蒸留酒の世界をつくり出している. ハンデの数が知
恵の数となり, 知恵の数がオリジナリティをつくり出し たのが焼酎の世界である，原料や製法，微生物が焼酎の 文化性を深めていると言っていい.

酒は醸造酒と蒸留酒に区分されるが，これは蒸留工程 を含むか含まないかの単純な分類であって，酒の本質的 世界とはそぐわないところがある，西洋的分類では，醇 造酒は食中酒で生活の酒, 蒸留酒はアルコール度の高い 致酔飲料ということになろうが，アジアの蒸留酒は食中 酒で生活の酒であり，アルコール度も高低まちまちであ る。中でも日本の焼酎は醸造酒と同等かそれより低い濃 度で飲まれ，食中酒でもあるという醸造酒的特性をむつ ことから，西洋的分類にはそぐわない．

焼酎学講座は, この蒸留酒らしから好魅力的な世界に 科学的光を当て，それを通じてアジア的蒸留酒の世界を 啓蒙し，国際ブランド化を図ることが大きな目標であ る。 そして，この焼酎の世界とそれをつくり上げた先人 の知恵に敬意を払い，焼酎文化亡技術を継承するととも に，広い視野をもち大局的な視点で世界の中の焼酎のあ るべき姿を考えられる人材を育成したい.

\section{プロフィル}

藤本 健造（Kenzo Fujimoto）＜略 歴 $>1992$ 年京都大学工学部合成化学科卒 業 / 1997 年同大学大学院工学研究科合 成・生物化学専攻博士後期課程修了 (工 博) /同年同専攻助手 $/ 2002$ 年北陸先端科 学技術大学院大学マテリアルサイエンス研 究科准教授，現在にいたる。この間，2002 〜2006 年 JSTさきがけ研究者（兼任） <研究テーマと抱負 $>$ 光を用いた遺伝子操 作法の開発と応用 $<$ 趣味 $>$ ボーリング，ド ライブ

松木 隆広 (Takahiro Matsuki) <略 歴>1995 年東京工業大学大学院生命理工 学研究科バイオサイエンス専攻修士課程修 了 $/ 2005$ 年東京大学大学院農学生命科学 研究科博士課程修了 (農博), 現在, (株) ヤ
クルト本社ヤクルト中央研究所 $<$ 研究テー マと抱負 $>$ 腸内フローラの分子生態学, 腸 内フローラと宿主の相互作用の研究 <趣 味 $>$ 海外旅行, 釣り, バドミントン

松㟝 益德 (Masunori Matsuzaki) $<$ 略歴 $>$ 昭和 47 年山口大学医学部医学科 卒業/平成 4 年同大学大学院医学研究科教 授, 現在にいたる.この間, 昭和 56 年米国 カリフォルニア大学サンディエゴ校留学 <研究テーマと抱負>心不全, 動脈硬化, 超音波医学 $<$ 趣味 $>$ 写真撮影, ドライブ, ゴルフ

宮 川 恒 (Hisashi Miyagawa) <略 歴 $>1980$ 年京都大学農学部農芸化学科卒 業 / 1982 年同大学大学院農学研究科修士
課程修了／1983 年武田薬品工業(株)農薬 事業部／1989年京都大学農学部助手／ 1995 年同助教授 / 1996 年同大学大学院農 学研究科助教授 $/ 2002$ 年同教授, 現在にい たる<研究テーマと抱負 $>$ 植物含窒素二次 代謝物の生合成・代謝 $<$ 趣味 $>$ 酒類賞味, 名曲鑑賞，ラグビー観戦

本 村 圭 (Kei Motomura) <略歴> 2005 年広島大学工学部第三類卒業 $/ 2007$ 年同大学大学院先端物質科学研究科分子生 命機能科学専攻博士課程前期修了 / 同年同 博士課程後期入学, 現在にいたるく研究 テーマと抱負>ポリリン酸の蓄積機構と生 理機能の解明<趣味>スポーツ観戦, バド ミントン 